\title{
Marxism underground. Latent Marxism in Austrian empirical sociology
}

\author{
Andreas Kranebitter · Christoph Reinprecht
}

(C) The Author(s) 2018

\begin{abstract}
The establishment of sociology in Austria in the twentieth century is in many ways connected with Marxism. Numerous sociologists considered themselves as Marxists, thus at least subjectively carrying on with an "underground" Marxism in their sociological work. Others spent considerable energy in distancing themselves sharply from Marxist positions and tried (especially in times of Austrofascism and National Socialism) to banish Marxism underground within the young discipline. This precarious tension continued to exist in the post-war period and shaped the establishment of sociology as an academic discipline in Austria, but remained unproductive. This thematic issue therefore raises the question of the "latency" of Marxist concepts and positions in Austrian empirical sociology and seeks to explore whether the discussion and updating of Marxist positions can stimulate reflection on the conditions of production of sociological knowledge and research.
\end{abstract}

Keywords Marxism - Sociology in Austria - History of empirical social research · Reflexive sociology

\section{Marxismus im Untergrund. Zur Latenz des Marxismus in der österreichischen empirischen Soziologie}

Zusammenfassung Die Entwicklung der Soziologie in Österreich ist im 20. Jahrhundert auf mehrfache Weise mit dem Marxismus verbunden. Zahlreiche SoziologInnen bezeichneten sich selbst als MarxistInnen und führten so zumindest subjektiv einen Marxismus ,,im Untergrund“ mit sich; andere grenzten sich in ihrem Verständnis scharf von marxistischen Positionen ab und versuchten (gerade in Zeiten des Austrofaschismus und Nationalsozialismus), den Marxismus in den Untergrund

A. Kranebitter $(\triangle) \cdot$ C. Reinprecht $(\triangle)$

Institut für Soziologie, Universität Wien, Rooseveltplatz 2, 1010 Wien, Austria

E-Mail: andreas.kranebitter@mauthausen-memorial.org; christoph.reinprecht@univie.ac.at 
der jungen Disziplin zu verbannen. Die Etablierung der Soziologie als akademische Disziplin in Österreich bedeutete in der Nachkriegszeit auch eine Festschreibung dieses prekären Spannungsverhältnisses, die für die Soziologie unproduktiv blieb. Das Themenheft möchte daher die Frage nach der Latenz marxistischer Konzepte und Positionen in der österreichischen empirischen Soziologie aufwerfen und erkunden, ob die Diskussion und Aktualisierung marxistischer Positionen zu einer Reflexion der Produktionsbedingungen soziologischer Forschung anregen kann.

Schlüsselwörter Marxismus · Soziologie in Österreich · Geschichte der empirischen Sozialforschung · Reflexive Soziologie

\section{Introduction}

From its early days, sociology, in Austria as elsewhere, has been a fragmented discipline. Under the influence of different ontological, epistemological and methodological backgrounds, it has and continues to break up into different strands. Academically, sociology has become established in a state of (mainly peaceful) coexistence of these separate spheres - the diversity of research agendas and publications, approaches and strands allegedly serving a sense of identity through professionalization. Against this background, it was stated that "due to (continually) dismantling itself into rivalling subdisciplines, sociology got lost. The result is a sociology without society and without history" (Dahmer 2001, p. $17 \mathrm{f}$; ; also see Gouldner 1974) ${ }^{1}$. Its form of existence indicates a specific relation to its own history: the canonization of a nationally organized yet disputed minimum consensus (Kaesler 2012). This lowest common denominator implies as well as provokes a conscious suppressing and unconscious forgetting of its uncomfortable roots, references, and debates. Notably Austrian sociology, which only began to take root in the universities in the 1950s, was based on this suppression. Here, the legacy of both Austrofascism and Nazism (Reinprecht 2014; Kranebitter and Horvath 2015) led to a lasting displacement of certain sociological traditions-not least (Austro-)Marxist ones.

Since the 19th century, numerous Austrian sociologists have considered themselves as Marxists. In a perspective from the outside, John Torrance captured this view in a nutshell: "For nowhere else did the sociological perspective develop so exclusively under the aegis of Marxism [...] and nowhere else was Marxism so consistently interpreted as sociology" (Torrance 1976, p. 192). Without historical contextualization, this dramatic intensification cannot claim universal validity. But besides the obvious self-denomination of some, others have expended considerable time and energy in differentiating themselves from Marxist positions. Whereas Paul Lazarsfeld called himself a "Marxist on leave" (Morrison 1976, p. 50) even in American exile, Othmar Spann wanted his Gesellschaftslehre to be understood as antithetically distinct from the "dead science" of Marxism (Spann 1921). If the former group carried on with an "underground" Marxism in their sociological work, the lat-

\footnotetext{
${ }^{1}$ All German references were translated by the editors, who take responsibility for any misunderstandings resulting from the translation.
} 
ter, conversely, tried to banish Marxism underground within the discipline. In both ways, the impact of Marxism on Austrian sociology can hardly be overestimated.

Against this background the current special issue has invited authors to locate and discuss Marxism found underground in sociology's history and epistemology, in particular in what might be termed the "latency" of empirical sociology. By latency, we mean a presence that is not directly observable but which erupts from time to time on the manifest surface. Has empirical sociology referred to Marx' empirical work (a topic discussed at length but which we cannot deal with in this editorial in detail; see e.g. the critique of Merton 1987) as well as Marxism at all? What kind of Marxism did it refer to, what concept of Marxism did it have in mind? Referring to the sociologist Max Adler, Christian Fleck stated that in general, Austromarxist sociologists saw their Marxism as an "empirical Marxism, which in sociological questions was to be regarded as the true sociology" (Fleck 1990, p. 100) and thus saw no need to establish connections with other sociological strands (ibid., p. 38). But where do authors with a Marxist training go beyond this kind of Marxism without sociology? Michael Burawoy and Eric Olin Wright recently noted that today, most sociologists are also "selectively using particular concepts and themes in the Marxist tradition to understand specific empirical problems" (Burawoy and Wright 2002, p. 459). But where does a productive connection between empirical sociology and Marxism go beyond ritualized forms of "automatic quotes" (Steinert 2010, p. 7 f.) and an instrumental relationship to Marxism, a kind of sociology without Marxism? The question underlying this issue is therefore whether and how a "Marxist underground" has helped to inform and establish a form of critical empirical social research that amounts to more than a blind and unconscious empiricism as a "spontaneous ideology of science" (Bourdieu 1975, p. 40; Steinmetz 2005, p. 35).

\section{Marxist sociologies and empirical research}

"At that time I had in mind two aberrations sociology needed to get away from, which were opposed to one another. The Frankfurt School stands for the first, which can be called 'theoreticistic', meaning people who are not doing social research but constantly denounce the positivist threat [...]. The second, which can be termed the 'positivist' one, was represented by Lazarsfeld. In short, the pair Lazarsfeld/Adorno" (Bourdieu 1991, p. 269). For many, Lazarsfeld and Adorno were the contrasting pair who represented the antithesis between theory and empiricism, each of which implied a certain epistemological standpoint. Numerous widely known empirical research projects were conducted under the auspices of the Frankfurt School (Horkheimer 1936; Adorno et al. 1950; Pollock 1955). Adorno and Horkheimer nevertheless criticized the "technification of sociology" (Institut für Sozialforschung 1983 [1956], p. 114) embodied by empirical research which classed the subjective views of respondents in ideological delusion as "facts" and thus took "Second Nature" at face value. Austrian sociologists, who frequently took part in the institute's research projects, were, like Lazarsfeld, considered as "subaltern experts for statistical analysis" (Fleck and Stehr 2007, p. 19). Empirical research, however, was not denied its right to exist altogether. Rather, Adorno saw it as a "healing correc- 
tive" to critical social theory (Adorno 2018 [1957], p. 208, 214), which seeks to determine the essence behind the empirically observable appearance, which, in turn, also constituted that essence. According to Adorno, both strands of sociology were irreducible to one another and should exist in peaceful coexistence, with "tensions to be dealt with productively" (ibid., p. 198).

After his emigration to the United States, Paul Lazarsfeld became virtually synonymous with social research (attribution and self-image corresponded in this regard), which felt an obligation to introduce and develop modern research techniques early on. The famous Marienthal study used sociography to address the "gap between the bare figures of official statistics and the literary accounts, open as they invariably are to all kinds of accidental impressions" (Jahoda et al. 2003, p. 1). ${ }^{2}$ Social theory was only referred to in the introduction added later to the study (Jahoda et al. 1975, p. $21 \mathrm{f}$.). According to his memoirs, Lazarsfeld's cooperation with Adorno was characterized by a mutual lack of understanding and was unproductive, "because the direction he [Adorno] gave could hardly be translated into empirical terms" (Lazarsfeld 1968, p. 324). What in retrospect looked like the incarnation of an "'apolitical' empiricism" (Pollak 1980, p. 157) had its theoretical roots in Austromarxism - to the extent that Lazarsfeld could even be called a "prototypical Austromarxist" (Fleck 1990, p. 143). From its beginnings, Austromarxism defined itself as genuinely practical. Max Adler and Rudolf Hilferding, two Austromarxists with a great affinity for sociology, felt bound to a methodical Marxism (Mozetic 1983, p. 10; see also Mozetič 1992). In 1908, Rudolf Goldscheid, the mastermind behind the Wiener Soziologische Gesellschaft founded shortly beforehand, wrote in what was to become one of the first — and well-nigh programmatic-lectures on the duties of sociology: "Social policy is applied sociology, as medical science is applied biology" (Goldscheid 1908, p. 231; ibid., p. 240; Exner 2013, p. 40-43; very similar: Neurath 1979 [1931], p. 185).

Lazarsfeld and Adorno, the two main Marxist-trained opponents within Germanspeaking sociology, had therefore situated themselves at either end of the epistemological spectrum. However, this positioning can also be interpreted as the theoretical articulation of a political misunderstanding. Whereas the practical approach must have appeared suspicious to the "Frankfurt side", social philosophy represented a tradition aloof and out of touch with political reality for the "Viennese". Beyond any real epistemological differences, as well as any incompatibilities constructed in sharp contrast to one another, positivism seems to have been a red rag to Adorno in the "positivism dispute" not least for political reasons. There certainly was a "tendency to equate 'positivism' with conservative partisanship, with a positive assessment of the status quo of dominant social relations which had to be criticized per se" (Ritsert 2010 , p. 108). On the other hand, Lazarsfeld's empiricism was a commitment to a "'modernism' epitomized by empiricism in comparison to the official training in social science at the University of Vienna" (Pollak 1981, p. 195).

\footnotetext{
2 In the German edition, Jahoda et al. write of statistics, not "official" statistics, and of "soziale Reportage" ("social reportage") instead of literary accounts (see Jahoda et al. 1975, p. 24), which refers to a whole tradition of its own connected to early Austrian sociology (see e.g. Winter 1982; Riesenfellner 1987).
} 


\section{Politics intersecting the epistemological matrix}

There were fundamental differences in the politics of the different strands within German and Austrian sociology. The political and epistemological matrices of both sociologies are not congruent. In Germany, the socio-philosophical tradition remained hegemonic on both the Left and the Right, with empirical research appearing to be either what arose and what was promoted as "expert knowledge" in the era of National Socialism (see e.g. Klingemann 2009) or what looked like an "import" from the USA. Quite contrarily in Austria, the sociological tradition embedded in the universities was a socio-philosophical one ranging from Catholic to fascist in character (Spann 1921; Günther 1940; both had, by the way, started their careers as empiricists), whereas empirical sociology was extramural, Marxist, Jewish and female-it is worth mentioning Käthe Leichter, Marie Jahoda, Lotte SchenkDanzinger, Elke Frenkel-Brunswick and Eva Köckeis in the post-war-era here-and was banned from or rather kept out of the universities as such. Extramural research beyond the ivory tower was thus exposed to multiple forms of intersectional marginalization and even forced to survive in third-party-funded market research and opinion polling. It was precisely this experience of marginalization that enabled innovation, as Lazarsfeld wrote, reflecting on his situation in American exile: "The institution man is a special case of a well-known sociological notion: the marginal man who is part of two different cultures. He lives under cross pressures that move him in a number of directions. According to his gifts and external circumstances he may become a revolutionary, a surrealist, a criminal. In some cases his marginality may become the driving force for institutional efforts" (Lazarsfeld 1968, p. 302).

But where are Marxist positions to be found in concrete empirical research projects or methodological considerations? When is - to paraphrase a well-known question put to Lazarsfeld - the holiday of the "Marxist on leave" over? The question of whether and how Marxism can be located in empirical sociology was the starting point for this issue. Put simply, our working hypothesis is that there is no connection: taking the memoirs of the main protagonists into account, empirical research and Marxism stood side by side in a relationship that was, at times, split in two. A "commitment" to Marxism and a self-image as a sociologist stood in direct juxtaposition with no efforts made to establish a connection between them. According to Christian Fleck, Lazarsfeld simply did not link a Marxism acquired from experience to the scientific skills and methods he had learned (Fleck 1990, p. 149). This also seems to hold true for Marie Jahoda, who spoke later of experiencing a scientific enlightenment when she lost her "faith" in Marxism due to the "facts' power of veto" (Fleck 2017, p. 284) to contradict Marxist theorems. "In a discussion," she wrote, "I made a fool of myself. Based on employment data, Rouai [sic-Zoltán Rónai] had stated that Marx' theory of a continuing polarization of classes was wrong. Are we to give up a theory only because some facts do not fit? I asked. Rouai [sic] was shocked by this disregard of the real world. I never forgot this lesson" (Jahoda 1997, p. 38). This statement reveals both a positivist epistemology—after all, the real world can be recognized through "facts"-and a view of Marxism, portraying it as a theory built not on empirical facts but rather a "blindness to the outside world" (ibid., p. 36; see also ibid., p. 134). In her dissertation, Jahoda replaced her earlier critical view 
that "job satisfaction" was neither observable empirically nor at all desirable given the need for political change towards socialism (Jahoda 1927) with a psychological model of life stages by psychologist Charlotte Bühler, which posited " $a$ number of universal laws of development" (Jahoda 2017, p. 33) over real life stories. Despite remaining critical of Bühler's thesis of "life fulfillment" (ibid., p. 115-117), a criticism based on Jahoda's own interviews, it is not only in the selection of life stories used to illustrate the thesis of a "normal life" (ibid., p. 45-50) that class analysis gets lost. For here at the latest, remnants of Marxism seem to have been exchanged for a positivist "regularity determinism", which basically states universal laws of history and society (Steinmetz 2005, p. 34).

The lack of connection between social research and Marxism has been the object of criticism before. According to Michael Pollak, Lazarsfeld's "socialist past became a sentimental quote, with political questions eliminated from his work" (Pollak 1981, p. 186). At times it was only an anecdotal statement. In an obituary of Lazarsfeld, the German sociologist Réne König celebrated Austromarxism's practical orientation as providing a closer link to empirical reality. "For him [Lazarsfeld], this primarily meant that his science and his political views were separated; science 'on duty' and politics 'after work' [...]. In order to properly understand this attitude, one has to take into consideration the key difference between Austromarxism and German Marxism; whereas the latter deals with 'debates on principles' (and thus-until today-mostly hovers in the air), Austromarxism has closer ties to historical reality, and thus to empirics, as the example of Karl Renner by itself shows" (König 2008, p. $121 \mathrm{f}$.). But, in keeping with our initial hypothesis, was Marxism indeed only a hobby pursued after work and while on leave?

\section{On using and building Sociological Marxism: The contributions to this volume}

The double understanding of underground Marxism in sociology described above is complemented at the level of theory by a third observation. The constellations of compromise within the sociological status quo, which are embedded nationally, always represent a precarious consensus. Times of societal crises herald successive "crises of sociology", shaking the discipline to its very foundations. Seen in this light, debating the conflictual relationship between Marxism and sociology could be a productive contribution to breaking up a false consensus, or even helping to remedy structural failures in sociology's subterranean foundations.

While beyond the disciplinary borders of sociology, in economics for example, Marxist theory and empirical methods have been brought—and thought- together (cf. e.g. Dunne 1991; Brenner 2003), such attempts have been rare notably in German-speaking sociology. In a more recent contribution to the debate, Michael Burawoy and Eric Olin Wright (2002) distinguish four stances in which sociology deals with Marxism as a social theory. Besides propagating and, secondly, burying Marxism — both variants treat Marxism as a doctrine and an ideology - a third stance uses Marxism as one source of ideas and concepts. A fourth mode goes beyond an understanding of Marxism as a catalogue of concepts, ideas and arguments. Instead 
it emphasizes the necessity of developing a sociological Marxism that explicates the political-normative dimension of capitalism's systemic transcendency (Burawoy and Wright 2002, p. 461; Wright 2017). The contributions in this thematic issue range between the third and fourth modes of this matrix.

The first two articles in this issue deal with class concepts in empirical social structure analysis. Whereas concepts around social class and wage labor inspired by Marxism found widespread use in the context of research on social structural change and the welfare state into the 1980s, these concepts all but disappeared over the following decades. Does this development reflect the socio-theoretical limitations of empirical sociology, or rather a specific distancing from Marxism? In their contribution, Hilde Weiss and Julia Hofmann examine how Austrian sociologists from 1945 to 1990 applied the concept of class. Research such as that done by Eduard März in the 1960s and Marina Fischer-Kowalski in the late 1970s show that there has been some continuity in references to Marx and Marxist debates in "Western Marxism"-for example, Nicos Poulantzas. Interestingly, this Marxist strand had developed in non-university research settings (Chamber of Labor and the Institute for Advanced Studies), a fact that may be interpreted as an institutional continuity of empirical sociology in Austria: the Chamber of Labor was the workplace of economist and sociologist Käthe Leichter who explicitly referred to "Marx as a sociologist" (Leichter 1973, p. 365) in her writings, such as the life memoirs written in prison. In her article, Carina Altreiter gives evidence that international openness may be an important feature contributing to post-war Austrian sociology overcoming its "autochthonous provincialization" (Fleck 1996). The article poses the question of where and how, following the decline of the long-lasting dominance of individualization theory and its individualized and subject-centered research strategies, industrial sociology and the sociology of work may once again operate with a Marxist understanding of social class. Pierre Bourdieu's concepts of class and habitus represent an approach that may serve as a model for possible bridge building.

In her contribution, Tine Haubner, co-editor of a recently published volume on Marxism and sociology (Haubner and Reitz 2018), takes up Marx's concept of exploitation with the aim of making it fruitful empirically in the analysis of care work. The conceptual elaboration of the term "exploitation" is carried out against the background of the ongoing transformation of the welfare state and the emerging care regime. Haubner proposes a "profanation" of Marx's concept of exploitation. Where for Marx every wage-labor relation is understood as a relation of exploitation, Haubner posits a concept of exploitation built around categories of economic and social vulnerability, social exclusion and devaluation, with underpayment and deprofessionalization as key indicators. Exploitation thus refers to the concept of $U n$ terschichtung, a positioning below the lowest status line and in the second, informal labor market.

The article by Roland Atzmüller responds in more general terms to the demand to develop sociological Marxism. How can Marxist-oriented theory work contribute to an emancipatory transformation of the system? The article addresses the "crisis of Marxism", which became evident not just in the context of the great "financial crisis" of 2008 but particularly in relation to the fundamental structural change from Fordism to post-Fordism. According to Atzmüller, critical, Marxist-inspired theory 
work can only be fruitful if the crises of Marxism are thought about in relation to their interaction with the continuous crises and transformations of capitalism. The transformative capacity of capitalism- "reproduction through change"-requires a diversified and polyphonic socio-critical theoretical practice.

This special issue brings together explorations into and attempts to "update" Marxist debates that have been buried within the history of empirical sociology in Austria. These explorations require development and contact with international debates in order to avoid coming to nothing or remaining fixed in a state of demanding an "empirical sociology free of metaphysics" instead of "addressing the subject matter itself' (Neurath 1982, p. 233), as Paul Neurath wrote of his father's books on "empirical sociology". Drawing on Atzmüller's line of argument, it can be said that it is not only the oft-proclaimed crisis of Marxism but of sociology as well that might stimulate a reflexive approach to one's own conditions of production. Traditional notions of a crisis in theory suggest the assumption of a supposedly consistent and coherent "theoretical structure", disregarding the conditions of existence of its own theoretical practice. Althusser's provocative war cry- "At last the crisis of Marxism has exploded! At last it is in full view! At last something vital and live can be liberated by this crisis and in this crisis!" (Althusser 1978, p. 59)—alludes to the productive rupture of the idea of a once-and-for-all unified theory of Marxism and demands an understanding of Marxism as a necessarily unfinished and openended project. This does not apply solely to Marxism: every sociological theory can be seen as related to social change and thus requiring appropriate self-critical reflection on its own conditions of production-nothing short of a sociological view on sociology. Following Bourdieu and the late Austrian sociologist Heinz Steinert, it can be argued that it is precisely this broad reflexivity - of the doxa of society and sociology - that might form the basis of a productive connection between Marxism and sociology, combining the choice of research topics and appropriate methodology with a socially active and effective research agenda. Then it will be "reflexivity's task to remember what is hidden in the self-evident. In doing so, the social scientist finds themself on the side of the loser, the deviant, the excluded, in structural as well as historical terms. The established order and its self-evidence care for themselves. We are in charge of contradiction" (Steinert 1998, p. 28; see also Resch and Steinert 2011, p. $11 \mathrm{f}$.).

\section{Between the chairs: Wilhelm Reich}

This special issue concludes with a text by Wilhelm Reich, introduced by Helmut Dahmer. Reich's early research is regarded as having a specific connection between Marxism and psychoanalysis, but is seldom associated with Austrian sociology (with the remarkable exception of Gallissot 1983) and was (like other dissident Marxist theories of fascism) also considered taboo by the Horkheimer Circle (Dahmer 2014, p. 83). In contrast to most other social scientists, Reich constantly moved between the various "Viennese Circles" (most recently see Peglau 2017 on Reich's activities in Vienna), which normally existed independently of each other. (The social form of circles thereby established a social rift between "proletarian" and "bourgeois" culture 
in Vienna (Steinert 1989, p. 19), which again may have contributed to the separation of politics and social research mentioned above.) Reich's text Ein praktischer Kursus in marxistischer Soziologie deals with the events of the so-called "Justizpalastbrand" in Vienna on July 15th, 1927, and thus provides an interesting empirical observation of an important phenomenon in contemporary Austrian history which should be read across disciplinary boundaries. Reich combines precise observation with an analysis of the political defeat of the social democratic workers' movement in Austria, as well as an analysis of the "incapacity to freedom" of the "mass-men". The text is introduced by Helmut Dahmer, one of the leading experts on Reich's works (see, e.g., Dahmer 1973); the text itself is printed in an abbreviated version by permission of Stroemfeld-Verlag. We want to thank Helmut Dahmer and both the Stroemfeld and Springer publishing houses for organizing copyright permission. Re-reading texts like Reich's does not mean searching for an "original Marxism" buried in the history of Austrian sociology. Philological "excavation works" might rather, as was the case in 1968 (Felsch 2016, p. 51), potentially help in a project of the "anamnesis of genesis" (Dahmer 2001, p. 8) of social institutions and scientific disciplines.

Funding Open access funding provided by University of Vienna.

Open Access This article is distributed under the terms of the Creative Commons Attribution 4.0 International License (http://creativecommons.org/licenses/by/4.0/), which permits unrestricted use, distribution, and reproduction in any medium, provided you give appropriate credit to the original author(s) and the source, provide a link to the Creative Commons license, and indicate if changes were made.

\section{References}

Adorno, Theodor W. 2018. Soziologische Schriften I. Gesammelte Schriften in 20 Bänden, Vol. 8. Berlin: Suhrkamp.

Adorno, Theodor W., Else Frenkel-Brunswik, Daniel J. Levinson, and R. Nevitt Sanford. 1950. The authoritarian personality. New York: Harper \& Brothers.

Althusser, Louis. 1978. Die Krise des Marxismus. Hamburg: VSA.

Bourdieu, Pierre. 1975. The specificity of the scientific field and the social conditions of the progress of reason. Social Science Information 14(6):19-47.

Bourdieu, Pierre. 1991. "Inzwischen kenne ich alle Krankheiten der soziologischen Vernunft". Pierre Bourdieu im Gespräch mit Beate Krais. In Soziologie als Beruf. Wissenschaftstheoretische Voraussetzungen soziologischer Erkenntnis, ed. Pierre Bourdieu, Jean-Claude Chamboredon, and Jean-Claude Passeron, 269-283. Berlin, New York: Walter de Gruyter.

Brenner, Robert. 2003. The boom and the bubble: the US in the world economy. London: Verso.

Burawoy, Michael, and Erik Olin Wright. 2002. Sociological Marxism. In Handbook of sociological theory, ed. Jonathan H. Turner, 459-486. New York: Kluwer Academic/Plenum Publishers.

Dahmer, Helmut. 1973. Libido und Gesellschaft. Studien über Freud und die Freudsche Linke. Frankfurt a. M.: Suhrkamp.

Dahmer, Helmut. 2001. Soziologie nach einem barbarischen Jahrhundert. Wien: WUV.

Dahmer, Helmut. 2014. Faschismustheorie(n) der "Frankfurter Schule". In Soziologie und Nationalsozialismus. Positionen, Debatten, Perspektiven, ed. Michaela Christ, Maja Suderland, 76-118. Berlin: Suhrkamp.

Dunne, Paul. 1991. Quantitative Marxism. Cambridge: Polity Press.

Exner, Gudrun. 2013. Die Soziologische Gesellschaft in Wien (1907-1934) und die Bedeutung Rudolf Goldscheids für ihre Vereinstätigkeit. Wien: new academic press.

Felsch, Philipp. 2016. Der lange Sommer der Theorie. Geschichte einer Revolte 1960-1990. Frankfurt a. M.: Fischer.

Fleck, Christian. 1990. Rund um "Marienthal". Von den Anfängen der Soziologie in Österreich bis zur ihrer Vertreibung. Wien: Verlag für Gesellschaftskritik. 
Fleck, Christian. 1996. Autochthone Provinzialisierung. Universität und Wissenschaftspolitik nach dem Ende der nationalsozialistischen Herrschaft in Österreich. Österreichische Zeitschrift für Geschichtswissenschaften 7(1):67-92.

Fleck, Christian. 2017. Marie Jahoda-ein Porträt. In Lebensgeschichtliche Protokolle der arbeitenden Klassen 1850-1930. Dissertation 1932, ed. Johann Bacher, Waltraud Kannonier-Finster, and Meinrad Ziegler, 267-361. Innsbruck, Wien, Bozen: Studien-Verlag.

Fleck, Christian, and Nico Stehr. 2007. Einleitung. Von Wien nach New York. In Empirische Analyse des Handelns. Ausgewählte Schriften, ed. Christian Fleck, Nico Stehr, 7-58. Frankfurt a. M.: Suhrkamp.

Gallissot, René. 1983. Austromarxismus. In Abhängigkeit bis Bund Kritisches Wörterbuch des Marxismus, Vol. 1, ed. Georges Labica, Wolfgang Fritz Haug, 126-132. Berlin: Argument.

Goldscheid, Rudolf. 1908. Soziologie und Geschichtswissenschaft. Annalen der Naturphilosophie 7:229-250.

Gouldner, Alvin W. 1974. Die westliche Soziologie in der Krise. Reinbek: Rowohlt. 2 Bände.

Günther, Adolf. 1940. Der Rassegedanke in der weltanschaulichen Auseinandersetzung unserer Zeit. Berlin: Junker und Dünnhaupt.

Haubner, Tine, and Tilman Reitz (eds.). 2018. Marxismus und Soziologie. Klassenherrschaft, Ideologie und kapitalistische Krisendynamik. Weinheim: Beltz Juventa.

Horkheimer, Max (ed.). 1936. Studien über Autorität und Familie. Forschungsberichte aus dem Institut für Sozialforschung. Paris: Alcan.

Institut für Sozialforschung. 1983. Soziologie und empirische Sozialforschung. In Soziologische Exkurse. Nach Vorträgen und Diskussionen, ed. Institut für Sozialforschung, 106-115. Frankfurt a. M.: Syndikat/EVA.

Jahoda, Marie. 1927. Arbeitsfreude, Kapitalismus, Arbeiterbewegung. Arbeit und Wirtschaft 5:317-320.

Jahoda, Marie. 1997. "Ich habe die Welt nicht verändert”. Lebenserinnerungen einer Pionierin der Sozialforschung. Frankfurt a. M., New York: Campus.

Jahoda, Marie. 2017. Lebensgeschichtliche Protokolle der arbeitenden Klassen 1850-1930. Innsbruck, Wien, Bozen: Studien-Verlag.

Jahoda, Marie, Paul F. Lazarsfeld, and Hans Zeisel. 1975. Die Arbeitslosen von Marienthal. Ein soziographischer Versuch. Frankfurt a. M.: Suhrkamp.

Jahoda, Marie, Paul F. Lazarsfeld, and Hans Zeisel. 2003. Marienthal. The sociography of an unemployed community. New Brunswick: Transaction Publishers.

Kaesler, Dirk. 2012. Was sind und zu welchem Ende studiert man die Klassiker der Soziologie? In Von Auguste Comte bis Alfred Schütz Klassiker der Soziologie, Vol. 1, ed. Dirk Kaesler, 11-38. München: C. H. Beck.

Klingemann, Carsten. 2009. Soziologie und Politik. Sozialwissenschaftliches Expertenwissen im Dritten Reich und in der frühen westdeutschen Nachkriegszeit. Wiesbaden: VS.

König, René. 2008. Wissenschaft und Sozialforschung. In memoriam Paul F. Lazarsfeld (1901-1976). In Paul Felix Lazarsfeld-Leben und Werk. Anstatt einer Biografie, ed. Wolfgang R. Langenbucher, 121-123. Wien: Braumüller.

Kranebitter, Andreas, and Kenneth Horvath. 2015. National socialism and the crisis of sociology. Österreichische Zeitschrift für Soziologie 40(2):121-128. https://doi.org/10.1007/s11614-015-0169-3.

Lazarsfeld, Paul F. 1968. An episode in the history of social research: a memoir. In Charles Warren center for studies in American history. Perspectives in American history, Vol. 2, 270-337. Cambridge: Harvard University Press.

Leichter, Käthe. 1973. Lebenserinnerungen. In Käthe Leichter-Leben und Werk, ed. Herbert Steiner, 231-381. Wien: Europaverlag.

Merton, Robert K. 1987. Three fragments from a sociologist's notebooks: Establishing the phenomenon, specified ignorance, and strategic research materials. Annual Review of Sociology 13:1-28.

Morrison, David Edward. 1976. Paul Lazarsfeld: the biography of an institutional innovator. Unveröffentlichte Dissertation.

Mozetič, Gerald. 1983. Einleitung. In Austromarxistische Positionen, ed. Gerald Mozetič, 7-28. Wien, Köln, Graz: Böhlau.

Mozetič, Gerald. 1992. Outsiders and true believers. Austrian sociologists respond to fascism. In Sociology responds to fascism, ed. Stephen P. Turner, Dirk Käsler, 14-41. London, New York: Routledge.

Neurath, Otto. 1979. Empirische Soziologie. In Wissenschaftliche Weltauffassung, Sozialismus und Empirismus, ed. Rainer Hegelsmann, 145-234. Frankfurt a. M.: Suhrkamp.

Neurath, Paul. 1982. Otto Neurath und die Soziologie. In Schlick und Neurath-ein Symposion, ed. Rudolf Haller, 223-240. Amsterdam: Rodopi. 
Peglau, Andreas. 2017. Revolutionärer Sozialdemokrat und Kommunist. Zur Rolle des Psychoanalytikers Wilhelm Reich in der österreichischen „Linken“ zwischen 1925 und 1930. Sozial. Geschichte Online 21:5-19.

Pollak, Michael. 1980. Paul F. Lazarsfeld: A sociointellectual biography. Knowledge. Creation, Diffusion, Utilization 2(2):157-177.

Pollak, Michael. 1981. Paul F. Lazarsfeld-Gründer eines multinationalen Wissenschaftskonzerns. In Geschichte der Soziologie. Studien zur kognitiven, sozialen und historischen Identität einer Disziplin, Vol. 3, ed. Wolf Lepenies, 157-203. Frankfurt a. M.: Suhrkamp.

Pollock, Friedrich. 1955. Gruppenexperiment. Ein Studienbericht. Frankfurt a. M.: Europäische VerlagsAnstalt.

Reinprecht, Christoph. 2014. Die österreichische Soziologie und der Nationalsozialismus. Aufbruch, Verdrängung und verletzte Identität. In Soziologie und Nationalsozialismus. Positionen, Debatten, Perspektiven, eds. Michaela Christ and Maja Suderland, 237-262. Berlin: Suhrkamp.

Resch, Christine, and Heinz Steinert. 2011. Kapitalismus: Porträt einer Produktionsweise. Münster: Westfälisches Dampfboot.

Riesenfellner, Stefan. 1987. Der Sozialreporter. Max Winter im alten Österreich. Wien: Verlag für Gesellschaftskritik.

Ritsert, Jürgen. 2010. Der Positivismusstreit. In Soziologische Kontroversen. Beiträge zu einer anderen Geschichte der Wissenschaft vom Sozialen, ed. Georg Kneer, Stephan Moebius, 102-130. Berlin: Suhrkamp.

Steinert, Heinz. 1989. Adorno in Wien. Über die (Un-)Möglichkeit von Kunst, Kultur und Befreiung. Wien: Verlag für Gesellschaftskritik.

Spann, Othmar. 1921. Tote und lebendige Wissenschaft: Abhandlungen zur Auseinandersetzung mit Individualismus und Marxismus. Jena: G. Fischer.

Steinert, Heinz. 1998. Reflexive Sozialforschung. In Zur Kritik der empirischen Sozialforschung. Ein Methodengrundkurs, ed. Heinz Steinert, 15-28. Unveröffentlichtes Typoskript.

Steinert, Heinz. 2010. Max Webers unwiderlegbare Fehlkonstruktionen. Die protestantische Ethik und der Geist des Kapitalismus. Frankfurt, New York: Campus.

Steinmetz, George. 2005. Positivism and its others in the social sciences. In The politics of methods in the human sciences. Positivism and its Epistemological others, ed. George Steinmetz, 1-56. Durham, London: Duke University Press.

Torrance, John. 1976. The emergence of sociology in Austria 1885-1935. European Journal of Sociology 17(2):185-219. https://doi.org/10.1017/S0003975600007359.

Winter, Max. 1982. Das schwarze Wienerherz. Sozialreportagen aus dem frühen 20. Jahrhundert. Wien: Österreichischer Bundesverlag.

Wright, Erik Olin. 2017. Reale Utopien. Wege aus dem Kapitalismus. Berlin: Suhrkamp.

Andreas Kranebitter Sociologist and political scientist in Vienna, 2014-2017 Fellow at the Department of Sociology at the University of Vienna, since 2017 Head of the Research Center at the Mauthausen Memorial.

Christoph Reinprecht Professor of Sociology at the University of Vienna. Research interests in the field of migration and urban studies, social inequality, and political sociology. 